\title{
BABY SMOKER: PERILAKU KONSUMSI ROKOK PADA ANAK DAN STRATEGI DAKWAHNYA
}

\author{
Hasyim Hasanah \\ IAIN Walisongo Semarang \\ email: hasyimhasanah_82@yahoo.co.id
}

\begin{abstract}
Abstrak
Anak merokok merupakan fenomena yang dianggap wajar oleh sebagian besar orang tua. Anak merokok dari tahun ketahun terus mengalami peningkatan yang cukup signifikan. Hal ini disebabkan karena banyak faktor, diantaranya faktor yang bersifat internal maupun eksternal, baik karena watak kebiasaan, maupun pengaruh dari lingkungan khususnya media massa. Pada beberapa kasus anak merokok memiliki dampak negative dalam perkembangan kehidupannya diantaranya efek berupa sakit fisik maupun psikologis, dan perilaku malasuai. Kondisi ini perlu diminimalisir agar perilaku merokok anak dapat diminimalisir. Salah satu upaya yang diduga dapat dilakukan untuk mengurangi peningkatan perilaku merokok adalah dengan upaya dakwah Islam dengan mengoptimalkan bentuk kegiatan dakwah yaitu irsyad, tabligh, tadbir, dan tathwir.
\end{abstract}

Kata Kunci: baby smoker, rokok, strategi dakwah

\section{A. Pendahuluan}

Beberapa headline news media cetak dan elektronik akhir-akhir ini begitu hangat memperbincangkan keberadaan Baby smoker. Beberapa media melansir dalam perkembangan dua tahun terakhir didapatkan kenyataan bahwa Indonesia disebut-sebut menjadi satu-satunya negara di dunia dengan baby smoker atau perokok anak. ${ }^{1}$ Cina khususnyaTiongkok merupakan negara nomor satu dalam konsumsi rokok yaitu sekitar 390 juta

1 Muliarta, "jangan kaget 1.2 juta anak Indonesia perokok aktif", lihat dalam http://www.citizenjurnalism.com/hot-topics/daily-snapshot/jangan-kaget-12-juta-anakindonesia-perokok-aktif/, diakses Selasa, 19 Pebruari 2013. 
perokok atau 29\% per penduduk, disusul India dengan 144 juta perokok atau $12,5 \%$ per penduduk dan Indonesia hanya sekitar 65 juta perokok dan menjadi negara terbesar ke-3 dengan jumlah perokok di dunia. Meskipun Cina menempati peringkat satu dunia dalam konsumsi rokok, hebatnya tidak ada anak-anak yang kedapatan mengkonsumsi rokok. Berbanding terbalik dengan Indonesia, sebagai negara berkembang yang menempati urutan ke tiga dunia dalam konsumsi rokok, ternyata Indonesia telah dinobatkan menjadi satu-satunya negara dengan baby smoker. ${ }^{2}$ Merupakan prestasi yang menyedihkan khususnya dalam pembentukan generasi muda yang sehat, dan kreatif.

Komisi Nasional Perlindungan Anak (Komnas Anak) melalui laporannya membuat kita tercengang, karena ternyata sebanyak 1,2 juta orang anak Indonesia berusia kurang dari 13 tahun sudah menjadi perokok aktif dan sekitar 293 ribu anak di bawah usia 10 tahun juga menjadi perokok aktif.' Dari laporan kementerian kesehatan RI didapatkan pada tahun 2007-2008 usia perokok anak-anak antara 10-14 tahun. Sedangkan pada tahun 20082012 terjadi percepatan usia dalam konsumsi rokok pada anak-anak yaitu kurang dari 5 tahun.

Di beberapa wilayah menunjukkan hasil yang semakin mencengangkan. Hasil Penelitian Aris (2012) di Sumatera Selatan terdapat bayi AS sejak usia 11 bulan telah menghisap rokok. AS diusianya menginjak 18 bulan telah menghisap rokok merek tertentu hampir 40 batang per hari. Kasus sama ditemukan pada AR usia 23 bulan berasal dari Manado. AR yang belum genap usia dua tahun ini setiap harinya telah menghabiskan 30-35 batang perhari. Sementara itu di Muba seorang balita berinisial RS usia 2 tahun 7 bulan menghabiskan 3 bungkus rokok sehari. ${ }^{4}$ Aris (2012) dalam penelitian-

${ }^{2}$ Pusat Komunikasi Publik Sekretariat Jendral Kementrian Kesehatan RI, “Laporan Global Adult Tobacco Survey (GATS)," Kementerian Kesehatan RI, 2012, hlm. 31.

${ }^{3}$ Pusat Komunikasi Publik Sekretariat Jendral Kementrian Kesehatan RI, "Laporan Global Adult Tobacco Survey (GATS)," hlm. 32.

4 Data Komnas Perlindungan Anak, lihat dalam http://www.tribunnews.com/ 2012/03/15/komnas-perlindungan-anak-desak-rpp-tembakau-disahkan, diakses Selasa, 19 Pebruari 2013. 
nya menyebutkan kecenderungan balita merokok dipicu adanya ketergantungan balita terhadap efek nikotin, koluena, arsenilun dan metanol yang terkandung di dalam tembakau rokok, dan apabila dikonsumsi balita akan menimbulkan reaksi kecemasan, kegelisahan dan tidak nyaman, sehingga apabila anak ini tidak diberikan rokok, maka akan menimbulkan reaksi emosi negatif seperti marah, mengamuk sampai membenturkan kepalanya sendiri. ${ }^{5}$

Realitas ini semakin miris jika semua orang tua dan masyarakat Indonesia mengetahui bahwa Indonesia dinobatkan sebagai satu-satunya negara di dunia dengan baby smoker atau perokok anak. Fenomena ini sering disebut dengan Kejadian Luar Biasa (KLB) yang memerlukan penyelesaian secepatnya dengan melibatkan berbagai elemen penting bangsa. Kita semua tahu bahwa anak-anak adalah generasi penerus bangsa. Kitapun tahu bahwa rokok menjadi akar berbagai penyakit yang dapat menurunkan produktivitas, baik perekok aktif maupun pasif. Ulasan tentang rokok pasti akan menuai pro dan kontra bagi masyarakat. Berbagai pertanyaan bagi pecinta rokok yang sebenarnya cenderung pembelaan diri adalah bagaimana dengan memperjuangkan nasib para petani tembakau? Disusul kemudian dengan pertanyaan nasib buruh pabrik rokok dan pailit bagi para produsen rokok. Belum lagi dengan pengurangan pemasukan pajak serta bea-cukai Negara, jika perusahaan rokok ditutup. Semua ini nampaknya menjadi dilema bagi masyarakat kita yang secara demografis merupakan negara yang sangat strategis mengembangkan tembakau sebagai bahan produksi utama rokok.

Pemerintah sebenarnya telah membuat kebijakan terkait dengan upaya mengurangi jumlah perokok, hanya saja antara komitmen dengan penegakan hukum belum dilakukan secara tegas. Menurut Nusrila Dewi, peran Pemerintah lokal dan sentral dalam rangka pembuatan kebijakan harus ditegakkan. Begitu pula dengan peran orang tua, masyarakat dan lingkungan sosial. Seluruh komponen bangsa harus memainkan peran strategisnya dalam mengurangi jumlah baby smoker di Indonesi yang mesih luput dari perhatian publik. Sementara itu menurut Ekowati Rahajeng

\footnotetext{
${ }^{5}$ Aris dalam Siti Wahyuningsih, Bebaskan Indonesia dari Baby Smoker, (Solo: Kementerian Kesehatan Kota Solo, 2012), hlm. 14.
} 
(2012), keluarga merupakan wahana pertama dan utama memberikan pengasuhan, perawatan, bimbingan, dan pendidikan dalam pemenuhan hak dan perlindungan anak, khususnya pada kasus KLB (Kejadian Luar Biasa) atau fenomena puncak gunung es Baby smoker.

Mendasarkan hal tersebut maka perlu kiranya makalah ini didiskusikan untuk menemukan informasi-informasi penting berkaitan dengan penanganan baby smoker, dan selanjutnya kontrubusi dari peserta diskusi ini mampu menemukan formulasi strategi dakwah yanng efektif, efisien dan tepat guna bagi upaya perlindungan anak di Indonesia.

\section{B. Baby Smoker}

Di Indonesia, angka baby smoker dari tahun ketahun semakin meningkat. Baby smoker adalah calon dan perokok jangka panjang dan menempatkan mereka pada kerusakan kualitas generasi dan kematian dini yang sebenarnya dapat dicegah. ${ }^{6}$ Merokok juga dianggap sebagai hal yang biasa dan normal. Bagi perokok umumnya mereka paham bahwa merokok mengakibatkan penyakit, tetapi menyangkal bahwa hal tersebut akan mengenai dirinya. Mereka berpendapat bahwa merokok adalah menarik, memudahkan pergaulan, mudah konsentrasi dan membuat hidup lebih mudah. Dampak ketagihan nikotin kurang disadari diantara perokok dini. Hal ini diasumsikan bahwa merokok hanya menjadi salah satu cara untuk bisa dianggap sebagai manusia dewasa yang dapat diterima oleh rekan dan lingkungannya. Alasan lain secara ekonomi. Rokok adalah barang yang mudah, dapat dibeli diberbagai tempat, mudah didapat dan tidak ada konsekuensi hukuman yang tegas dari pemerintah. Bahkan hal lain yang menjadikan perokok usia muda semakin banyak dan tidak terkendali adalah lingkungan khususnya keluarga yang seakan tidak mau peduli dengan apa yang dilakukan para anak usia dini ini.

Menurut RPP tentang Pengamanan Produk Tembakau sebagai zat adiktif bagi Kesehatan, atau dikenal dengan RPP Tembakau, batasan usia

${ }^{6}$ UHAMKA, Komnas P Anak. Dampak Keterpajangan Iklan Promosi dan Sponsor Rokok terhadap Kognisi, Afeksi dan Perilaku Merokok Anak. Jakarta, 2007. 
merokok secara nasional adalah 18 tahun, baik untuk penjualan, pendistribusian, maupun pemakaian. Berdasarkan RPP ini tentu menjadi ramburambu bagi semua pihak untuk dapat memberikan perlindungan khususnya anak-anak, jangan sampai mereka dapat mengakses ataupun menggunakan rokok.

Ketergantungan terhadap produk tembakau sangat tepat dianggap sebagai penyakit khronis dengan remisi dan relaps. Walaupun telah dilakukan intervensi baik minimal maupun intensif untuk berhenti merokok, tetapi umumnya perokok dengan bantuan berhenti merokok akan mengalami kambuhan dan membutuhkan pengulangan intervensi sebelum akhirnya benar-benar berhasil berhenti merokok.

\section{Faktor Penyebab Baby smoker}

Fenomena baby smoker merupakan fenomena luar biasa dan menjadi fenomena gunung es yang kurang mendapatkan perhatian publik. Faktor yang diduga menjadi pemicu meningkatnya baby smoker diantaranya sebagai berikut:

\section{Faktor Internal}

Faktor internal adalah faktor yang bersifat dari dalam diri individu. Faktor ini secara langsung memiliki keterkaitan dengan maslah kepribadian individu.

a. Rasa ingin tahu. Masa kanak-kanak merupakan masa pengenalan terhadap lingkungan sosial. Dalam masa ini anak akan sangat memperhatikan apa yang dilakukan oleh sekelilingnya. Keingin tahuan ini diwujudkan dalam meniru berbagai perilaku orang-orang di sekitarnya. Anak cenderung memiliki rasa keingin tahuan yang sangat besar. Terkait dengan perilaku anak, rasa keingin tahuan ini dapat didukung oleh keinginan menjadi sama dengan perilaku di sekelilingnya. ${ }^{7}$

b. Aspek kepribadian. Masa kanak-kanak merupakan masa pembentukan dan perkembangan kepribadian pada anak. Apabila keluarga tidak

${ }^{7}$ FJ. Monks, Psikologi Perkembangan, (Yogyakarta: UGM Press, 2006), hlm. 119. 
mengarahkan pembentukan dan perkembangan kepribadian, maka akan membuat anak mengalami gangguan pemrkembangan atau bahkan mengalami percepatan gangguan kepribadian.

c. Perkembangan emosi anak.

d. Kebiasaan anak.

\section{Fakter Eksternal}

Faktor eksternal adalah faktor-faktor yang bersifat dari luar individu yang mempengaruhi terjadinya baby smoker.

a. Iklan dan promosi rokok telah mengepung dari segala penjuru, di dalam dan di luar rumah. Bahkan, seringkali iklan dan promosi rokok ini mengiringi berbagai acara dan kegiatan yang diikuti kalangan anak dan remaja. Dengan kekuatan visualnya, iklan-iklan ini menyampaikan pesan perokok sebagai sosok yang keren, berani, percaya diri, kreatif dan setia kawan. Sangat mudah menggiring anak dan remaja, yang tengah mencari jati diri, untuk menjadi perokok pemula.

b. Lingkungan dan keluarga. Lingkungan keluarga dan masyarakat selama ini kurang mempedulikan baby smoker, karena merokok merupakan hal yang dianggap wajar. Bahkan tak jarang perilaku baby smoker timbul karena anggota keluarga dan masyarakat mengknsumsi rokok. Sehingga memungkinkan anak meniru perilaku anggota keluarga lainnya.

c. Pendidikan. Rendahnya tingkat pendidikan masyarakat Indonesia, diduga menjadi faktor pemicu baby smoker. Rata-rata penduduk Indonesia menjadi perokok aktif kebanyakan berpendidikan rendah, sehingga tidak memiliki pengetahuan mengenai rokok dan dampaknya bagi kesehatan.

d. Industrialisasi. Berdasarkan hasil penelitian yang dilakukan WHO (World Health Organization) tahun 2012 banyaknya perokok di negara berkembang dan maju disebabkan berkembangnya pusat industri tembakau di kawasan itu. Semakin banyak industri rokok di suatu wilayah akan berpengaruh pada tingkat konsumsi rokok masyarakat dikawasan tersebut.

e. Iklim/geografis. Wilayah yang secara geografis memiliki kontur tanah di daerah perbukitan atau pegunungan, menyumbangkan andil dalam 
peningkatan pola konsumsi rokok, iklim dingin biasanya cocok untuk tanaman tembakau dan memungkinkan masyarakatnya menghangatkan diri dengan mengonsumsi rokok.

f. Ekonomi. Murahnya harga rokok di Indonesia menurut Aris (2012) juga menjadi faktor pemicu banyaknya baby smoker di Indonesia. Berbeda dengan Cina dan India. Pemerintah membuat kebijakan tegas dalam penjualan rokok. Kalau di Indonesia satu batang rokok dapat diperoleh dengan harga seribu rupiah. Pemerintah Tiongkok mematok harga rokok hingga kisaran 45.000/batang.

g. Mainan Anak. Banyak mainan anak yang dibuat menyerupai rokok seperti produk permen, coklat, dan lain sebagainya, menyebabkan anak semakin mudah mengenal rokok dan mengetahui bagaimana cara mengkonsumsinya.

\section{Dampak Baby smoker}

Merokok pada anak membawa dampak yang begitu komplek khususnya dalam perkemabangan dan pertumbuhan seluruh sistem dan organ fitalnya (seperti jantung, paru, syaraf senso dan motorik sert kecerdasan). Selain dampak secara fisik, merokok pada anak (baik aktif maupun pasif) secara psikis akan merangsang timbulnya tekanan emosi berupa rasa cemas, was-was dan terkadang menimbulkan kemalasan, perilaku asertif, dan agresif (khusus pada perokok aktif). ${ }^{8}$

Berikut akan diinformasikan beberapa dampak merokok yang ditimbulkan dari kandungan zat pada rokok/tembakau: ${ }^{9}$

1. Nikotin merupakan Zat yang paling sering dibicarakan dan diteliti orang, meracuni saraf tubuh, meningkatkan tekanan darah, menimbulkan penyempitan pembuluh darah tepi, dan menyebabkan ketagihan dan ketergantungan pada pemakainya. Kadar nikotin 4-6 mg yang

8 live is grace I Bahaya Merokok Bagi Kesehatan, Lihat dalam http://w3nny.student. umm.ac.id/2010/02/04/bahaya-merokok-bagi-kesehatan/, diakses 25 Pebruari 2013.

${ }^{9}$ U.S. Department of Health and Human S ervices, Reducing Tobacco Use: A Report of the Surgeon General-Rxecutive Summary. Atlanta, (Georgia: U.S. Department of Health and Human Services, Centers for Disease Control and Prevention, National Center for Chronic Disease Prevention and Health Promotion, Office on Smoking and Health, 2000), hlm. 21. 
diisap oleh orang dewasa setiap hari sudah bisa membuat seseorang ketagihan. Di Amerika Serikat, rokok putih yang beredar di pasaran memiliki kadar 8-10 g nikotin per batang, sementara di Indonesia berkadar nikotin $17 \mathrm{mg}$ per batang.

2. Timah Hitam $(\mathrm{Pb})$. Timah hitam yang dihasilkan oleh sebatang rokok sebanyak 0,5 ug. Sebungkus rokok (isi 20 batang) yang habis diisap dalam satu hari menghasilkan $10 \mathrm{ug}$. Sementara ambang batas bahaya timah hitam yang masuk ke dalam tubuh adalah $20 \mathrm{~g}$ per hari. Bisa dibayangkan, bila seorang anak mengkonsumsi rokok berat menghisap rata-rata 1 bungkus rokok per hari, berapa banyak zat berbahaya ini masuk ke dalam tubuh.

3. Gas Karbonmonoksida (CO). Karbon Monoksida memiliki kecenderungan yang kuat untuk berikatan dengan hemoglobin dalam selsel darah merah. Seharusnya, hemoglobin ini berikatan. Dengan oksigen yang sangat penting untuk pernapasan sel-sel tubuh, tapi karena gas CO lebih kuat daripada oksigen, maka gas CO ini merebut tempatnya di sisi hemoglobin. Jadilah, hemoglobin bergandengan dengan gas $\mathrm{CO}$. Kadar gas CO dalam darah bukan perokok kurang dari 1 persen, sementara dalam darah perokok mencapai 4-15 persen.

4. TAR. TAR adalah kumpulan dari beribu-ribu bahan kimia dalam komponen padat asap rokok, dan bersifat karsinogen. Pada saat rokok dihisap, TAR masuk ke dalam rongga mulut sebagai uap padat. Setelah dingin, akan menjadi padat dan membentuk endapan berwarna cokelat pada permukaan gigi, saluran pernapasan, dan paruparu. Pengendapan ini bervariasi antara 3-40 mg per batang rokok, sementara kadar TAR dalam rokok berkisar $24-45 \mathrm{mg}$.

Merokok selain memiliki dampak jangka pendek, perilaku merokok juga memiliki dampak jangka panjang yang tidak hanya bagi anak, tetapi juga pada orang dewasa, baik perokok aktif maupun perokok tidak aktif:

1. Kerusakan paru-paru. Merokok dapat menyebabkan perubahan struktur dan fungsi saluran napas dan jaringan paru-paru. Pada saluran napas besar, sel mukosa membesar (hipertrofi) dan kelenjar mucus bertambah banyak (hiperplasia). Pada saluran napas kecil, terjadi radang ringan hingga penyempitan akibat bertambahnya sel dan 
penumpukan lendir. Pada jaringan paru-paru, terjadi peningkatan jumlah sel radang dan kerusakan alveoli. Akibat perubahan anatomi saluran napas, pada perokok akan timbul perubahan pada fungsi paruparu dengan segala macam gejala klinisnya. Hal ini menjadi dasar utama terjadinya penyakit obstruksi paru menahun (PPOM). Dikatakan merokok merupakan penyebab utama timbulnya PPOM, termasuk emfisema paru-paru, bronkitis kronis, dan asma. Hubungan antara merokok dan kanker paru-paru telah diteliti dalam 4-5 dekade terakhir ini. Didapatkan hubungan erat antara kebiasaan merokok, terutama sigaret, dengan timbulnya kanker paru-paru. Bahkan ada yang secara tegas menyatakan bahwa rokok sebagai penyebab utama terjadinya kanker paru-paru. Partikel asap rokok, seperti benzopiren, dibenzopiren, dan uretan, dikenal sebagai bahan karsinogen. Juga tar berhubungan dengan risiko terjadinya kanker. Dibandingkan dengan bukan perokok, kemungkinan timbul kanker paru-paru pada perokok mencapai 10-30 kali lebih sering.

2. Jantung. Banyak penelitian telah membuktikan adanya hubungan merokok dengan penyakit jantung koroner (PJK). Dari 11 juta kematian per tahun di negara industri maju,WHO melaporkan lebih dari setengah (6 juta) disebabkan gangguan sirkulasi darah, di mana 2,5 juta adalah penyakit jantung koroner dan 1,5 juta adalah stroke. Survei Depkes RI tahun 1986 dan 1992, mendapatkan peningkatan kematian akibat penyakit jantung dari 9,7 persen (peringkat ketiga) menjadi 16 persen (peringkat pertama). Merokok menjadi faktor utama penyebab penyakit pembuluh darah jantung tersebut. Bukan hanya menyebabkan penyakit jantung koroner, merokok juga berakibat buruk bagi pembuluh darah otak dan perifer. Asap yang diembuskan para perokok dapat dibagi atas asap utama (main stream smoke) dan asap samping (side stream smoke). Asap utama merupakan asap tembakau yang dihirup langsung oleh perokok, sedangkan asap samping merupakan asap tembakau yang disebarkan ke udara bebas, yang akan dihirup oleh orang lain atau perokok pasif. Telah ditemukan 4.000 jenis bahan kimia dalam rokok, dengan 40 jenis di antaranya bersifat karsinogenik (dapat menyebabkan kanker), di mana bahan racun ini lebih banyak didapatkan pada asap samping, misalnya karbon monoksida (CO) 5 
kali lipat lebih banyak ditemukan pada asap samping daripada asap utama, benzopiren 3 kali, dan amoniak 50 kali. Bahan-bahan ini dapat bertahan sampai beberapa jam lamanya dalam ruang setelah rokok berhenti. Umumnya fokus penelitian ditujukan pada peranan nikotin dan CO. Kedua bahan ini, selain meningkatkan kebutuhan oksigen, juga mengganggu suplai oksigen ke otot jantung (miokard) sehingga merugikan kerja miokard. Nikotin mengganggu sistem saraf simpatis dengan akibat meningkatnya kebutuhan oksigen miokard. Selain menyebabkan ketagihan merokok, nikotin juga merangsang pelepasan adrenalin, meningkatkan frekuensi denyut jantung, tekanan darah, kebutuhan oksigen jantung, serta menyebabkan gangguan irama jantung. Nikotin juga mengganggu kerja saraf, otak, dan banyak bagian tubuh lainnya. Nikotin mengaktifkan trombosit dengan akibat timbulnya adhesi trombosit (penggumpalan) ke dinding pembuluh darah.

3. Karbon monoksida menimbulkan desaturasi hemoglobin, menurunkan langsung persediaan oksigen untuk jaringan seluruh tubuh termasuk miokard. CO menggantikan tempat oksigen di hemoglobin, mengganggu pelepasan oksigen, dan mempercepat aterosklerosis (pengapuran/penebalan dinding pembuluh darah). Dengan demikian, CO menurunkan kapasitas latihan fisik, meningkatkan viskositas darah, sehingga mempermudah penggumpalan darah. Nikotin, $\mathrm{CO}$, dan bahan-bahan lain dalam asap rokok terbukti merusak endotel (dinding dalam pembuluh darah), dan mempermudah timbulnya penggumpalan darah. Di samping itu, asap rokok mempengaruhi profil lemak. Dibandingkan dengan bukan perokok, kadar kolesterol total, kolesterol LDL, dan trigliserida darah perokok lebih tinggi, sedangkan kolesterol HDL lebih rendah.

4. Ganggu Kesehatan Jiwa. Merokok berkaitan erat dengan disabilitas dan penurunan kualitas hidup. Dalam sebuah penelitian di Jerman sejak tahun 1997-1999 yang melibatkan 4.181 responden, disimpulkan bahwa responden yang memilki ketergantungan nikotin memiliki kualitas hidup yang lebih buruk, dan hampir 50\% dari responden perokok memiliki setidaknya satu jenis gangguan kejiwaan. Selain itu diketahui pula bahwa pasien gangguan jiwa cenderung lebih sering menjadi perokok, yaitu pada $50 \%$ penderita gangguan jiwa, $70 \%$ 
pasien maniakal yang berobat rawat jalan dan 90\% dari pasien-pasien skizrofen yang berobat jalan. Berdasaran penelitian dari CASA (Columbian University's National Center On Addiction and Substance Abuse), remaja perokok memiliki risiko dua kali lipat mengalami gejala-gejala depresi dibandingkan remaja yang tidak merokok. Para perokok aktif pun tampaknya lebih sering mengalami serangan panik dari pada mereka yang tidak merokok Banyak penelitian yang membuktikan bahwa merokok dan depresi merupakan suatu hubungan yang saling berkaitan.

Depresi menyebabkan seseorang merokok dan para perokok biasanya memiliki gejala-gejala depresi dan kecemasan (ansietas). Sebagian besar penderita depresi mengaku pernah merokok di dalam hidupnya. Riwayat adanya depresi pun berkaitan dengan ada tidaknya gejala putus obat (withdrawal) terhadap nikotin saat seseorang memutuskan berhenti merokok. Sebanyak $75 \%$ penderita depresi yang mencoba berhenti merokok mengalami gejala putus obat tersebut. Hal ini tentunya berkaitan dengan meningkatnya angka kegagalan usaha berhenti merokok dan relaps pada penderita depresi. Selain itu, gejala putus zat nikotin mirip dengan gejala depresi. Namun, dilaporkan bahwa gejala putus obat yang dialami oleh pasien depresi lebih bersifat gejala fisik misalnya berkurangnya konsentrasi, gangguan tidur, rasa lelah dan peningkatan berat badan). Nikotin sebagai obat gangguan kejiwaan Merokok sebagai salah satu bentuk terapi untuk gangguan kejiwaan masih menjadi perdebatan yang kontroversial.

Gangguan kejiwaan dapat menyebabkan seseorang untuk merokok dan merokok dapat menyebabkan gangguan kejiwaan, walau jumlahnya sangat sedikit, sekitar $70 \%$ perokok tidak memiliki gejala gangguan jiwa. Secara umum merokok dapat menyebabkan peningkatan konsentrasi, menekan rasa lapar, menekan kecemasan, dan depresi. Dalam beberapa penelitian nikotin terbukti efektif untuk pengobatan depresi. Pada dasarnya nikotin memberikan peluang yang menjanjikan untuk digunakan sebagai obat psikoaktif. Namun nikotin memiliki terapheutic index yang sangat sempit, sehingga rentang antara dosis yang tepat untuk terapi dan dosis yang bersifat toksis sangatlah sempit. Sehingga dipikirkan suatu bentuk pemberian nikotin tidak dalam bentuk murni 
tetapi dalam bentuk analognya. Namun, kerangka pemikiran pemberian nikotin sebagai obat tidaklah dalam bentuk kebiasaan merokok. Seperti halnya morfin yang digunakan sebagai obat analgesik kuat (penahan rasa sakit), pemberiannya harus dalam pengawasan dokter. Gawatnya, saat ini nikotin bisa didapatkan dengan bebas dan mudah dalam sebatang rokok, hal ini perlu diwaspadai karena kebiasaan merokok tidak lantas menjadi sebuah pembenaran untuk pengobatan gejala gangguan kejiwaan.

5. Sistem Reproduksi. Studi tentang rokok dan reproduksi yang dilakukan sepanjang 2 dekade itu berkesimpulan bahwa merokok dapat menyebabkan rusaknya sistem reproduksi seseorang mulai dari masa pubertas sampai usia dewasa Pada penelitian yang dilakukan Dr. Sinead Jones, direktur The British Medical Assosiation's Tobacco Control Resource Centre, ditemukan bahwa wanita yang merokok memiliki kemungkinan relatif lebih kecil untuk mendapatkan keturunan. pria akan mengalami 2 kali resiko terjadi infertil (tidak subur) serta mengalami resiko kerusakan DNA pada sel spermanya. Sedangkan hasil penelitian pada wanita hamil terjadi peningkatan insiden keguguran. Penelitian tersebut mengatakan dari 3000 sampai 5000 kejadian keguguran per tahun di Inggris, berhubungan erat dengan merokok. 120.000 pria di Inggris yang berusia antara 30 sampai 50 tahun mengalami impotensi akibat merokok. Lebih buruk lagi, rokok berimplikasi terhadap 1200 kasus kanker rahim per tahunnya.

6. Wanita merokok, menopause dini. Perempuan yang merokok sangat mungkin untuk mulai memasuki masa menopause sebelum usia 45 tahun dan juga membuat mereka menghadapi resiko osteoporosis dan serangan jantung, demikian laporan beberapa peneliti Norwegia. "Di antara sebanyak 2.123 perempuan yang berusia 59 sampai 60 tahun, mereka yang saat ini merokok, 59\% lebih mungkin mengalami menopause dini dibandingkan dengan perempuan yang tidak merokok," kata Dr. Thea F. Mikkelsen dari University of Oslo dan rekannya. Bagi perokok paling berat, resiko menopause dini hampir dua kali lipat. Namun, perempuan yang dulunya merokok, tapi berhenti setidaknya 10 tahun sebelum menopause, pada dasarnya kurang mungkin untuk berhenti menstruasi, dibandingkan dengan perokok sebelum usia 45 
tahun. Ada bukti bahwa merokok belakangan dalam kehidupan membuat seorang perempuan lebih mungkin untuk mengalami menopause dini, sedangkan perokok yang berhenti sebelum berusia setengah baya mungkin tak terpengaruh, kata Mikkelsen dan timnya di dalam jurnal Online, BMC Public Health. Mereka meneliti hubungan lebih lanjut dan menetapkan apakah menjadi perokok pasif juga mungkin mempengaruhi waktu menopause. Para peneliti tersebut mendapati bahwa hampir $10 \%$ perempuan memasuki menopause sebelum usia 45 tahun.

\section{E. Keuntungan Berhenti Merokok}

Berhenti merokok pada usia berapapun selalu menguntungkan. Semakin cepat berhenti merokok, fungsi paru akan menjadi semakin baik, kematian dan kecacatan karena penyakit akibat rokok dapat dicegah. Gambar di bawah menunjukkan fungsi paru yang berjalan bersamaan dengan peningkatan umur pada perokok yang berhenti merokok dan bukan perokok. Pada perokok tetap yang rentan terhadap dampak merokok, fungsi parunya menurun lebih cepat pada umur yang lebih dini dibandingkan bukan perokok. Lebih cepat berhenti merokok lebih baik. Sebagai contoh, berhenti merokok pada usia 45 tahun dapat memperbaiki fungsi paru dan mencegah kecacatan. Sekalipun berhenti merokok dilakukan pada usia lebih lanjut (misal 65 tahun), fungsi paru masih berpotensi untuk menjadi lebih baik dan umur harapan hidup diperpanjang.

Pada kasus anak-anak, berhenti merokok di usia dini akan mempengaruhi tingkat perkembangan dan pertumbuhan anak. Pada usia 0-5 tahun anak cenderung mengalami perkembangan kognitif, sensosik dan psikomotorik. Masa ini merupakan salah satu masa menentukan perkembangan selanjutnya. Tidak merokok di usia ini berarti telah membantu pertumbuhan dan perkembangan kemampuan seso-motorik pada anak. Pada rentang usia 5-10 tahun merupakan masa perkembangan hormonal dan sosial pada anak. Dengan berhenti merokok pada usia ini, maka pertumbuhan hormonal dan sosial dapat tercapai secara optimal..$^{10}$ Pada

${ }^{10}$ Atmarita, “Nutrition Problems In Indonesia”, makalah, "An Integrated International Seminar and Workshop on Lifestyle - Related Diseases", (Yoygyakarta: Gajah Mada University, 19-20 March, 2005). 
awalnya berhenti merokok membutuhkan perjuangan yang sangat berat. Jangan kaget bila ada tanda-tanda seperti mudah marah, sulit mengendalikan perasaan, kurang konsentrasi, gelisah, sulit tidur, batuk, penurunan denyut nadi, serta nafsu makan bertambah. Fase ini disebut fase withdrawal. Akan hilang sendiri setelah tiga sampai empat minggu.

\section{Fungi Paru pada Perokok yang Berhenti Merokok dan Bukan Perokok}

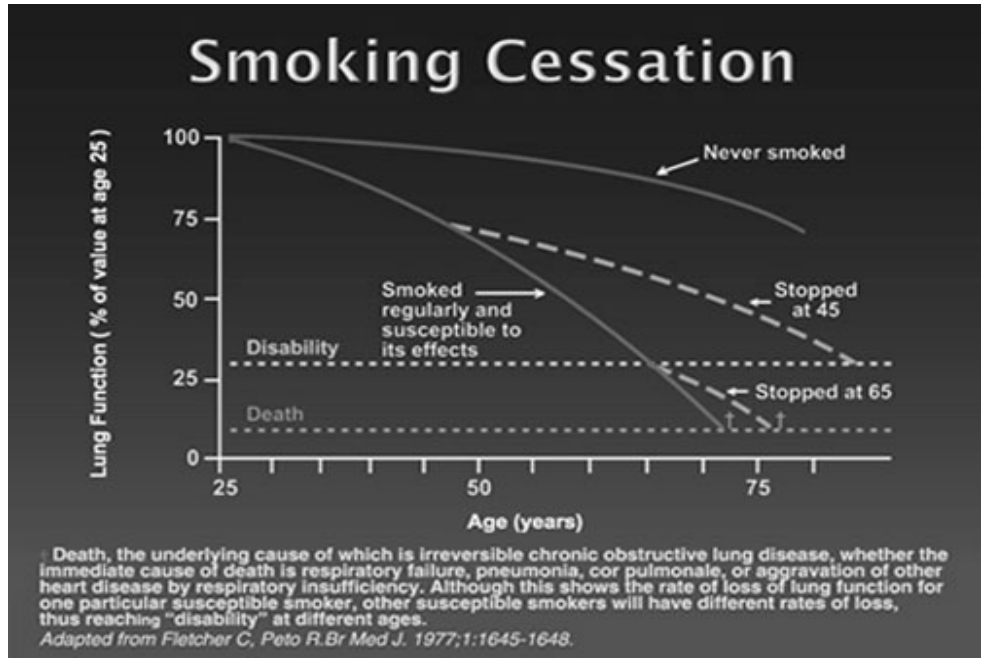

Perubahan pada tubuh setelah berhenti merokok: ${ }^{11}$

1. Dalam 20 menit : tekanan darah dan denyut nadi kembali normal.

2. Dalam 8 jam : kadar oksigen darah kembali ke normal.

3. Dalam 24 jam :CO dieliminasi dari tubuh.

4. Paru mulai mengeluarkan reak dan kotoran. Dalam 48 jam, nikotin tidak dapat lagi dideteksi dalam tubuh.

5. Kemampuan pengecapan dan penciuman lebih baik. Dalam 72 jam, bernafas terasa lega karena bronkhus lebih elastis.

11 Tjandra Y Aditama, Masalah Merokok dan Penanggulangannya, Jakarta: Yayasan Penerbitan IDI bekerjasama dengan PDPI dan LM3, 2001). 
6. Energi lebih meningkat. Dalam 2-12 minggu: sirkulasi darah di berbagai bagian tubuh membaik. Dalam 3-9 bulan: gangguan pernafasan seperti batuk, sesak, membaik.

7. Secara keseluruhan fungsi paru meningkat $5-10 \%$.

Dalam jangka panjang, berhenti merokok memberikan manfaat sebagai berikut: ${ }^{12}$

1. Dalam 1 tahun, resiko serangan jantung berkurang separuhnya.

2. Dalam 5 tahun, resiko kematian karena kanker paru dan kanker mulut turun $50 \%$.

3. Dalam 10 tahun, resiko kematian karena kanker paru dan stroke menurun sama dengan resiko bukan perokok.

4. Dalam 15 tahun, resiko serangan jantung menurun sama dengan resiko bukan perokok.

\section{F. Upaya Strategis Menanggulangi Baby Smoker}

Keinginan untuk terus merokok disebabkan karena kuatnya ketergantungan terhadap nikotin. Dibutuhkan kemauan yang kuat untuk berhenti merokok disamping dukungan lingkungan dan bantuan medik.

Beberapa teknik untuk berhenti merokok adalah ${ }^{13}$ :

1. Pendekatan perilaku (dengan konseling) dengan beberapa pilihan:

a. Berhenti seketika (cold turkey) atau

b. Berhenti bertahap melalui Pengurangan bertahap dari jumlah rokok yang diisap dan

c. Penundaan waktu mulainya merokok setiap hari.

Untuk anak uasia 0-5 tahun cold turkey dilakukan dengan tidak memberinya kemudahan dalam mengakses rokok, menjauhkan

12 Vibrant Life. How to Stop Smoking for Life. Vibrant Life: Special Issue no date, hlm. 6. dalam www.vibrantlife.com, diakses 25 Pebruari 2013.

${ }^{13}$ Martini, Santi. Muji Sulistiowati. The Determinants of Smoking Behavior among Teenagers in East Java Province, Indonesia: Health, Nutrition and Population (HNP) Discussion Paper Economics of Tobacco Control Paper No. 32. HNP, the World Bank, TFI WHO. December 2005. www.worldbank.org/hnp and www.worldbank. org/tobacco, diakses 23 Pebruari 2013. 
segala bentuk atribut rokok, meskipun pada beberapa balita melakukan perilaku agresif seperti membenturkan, memukul kepalanya, bahkan mengarah pada perusakan diri, orang tua tidak dianjurkan untuk menuruti keinginan anak. Cara ini cenderung sulit dilakukan pada beberapa balita yang sudah terkena dampak nikotin, koluena, arsenilun dan metanol sekaligus.

2. Pendekatan farmako terapi:

a. Terapi Pengganti Nikotin (plester, permen karet, spray dan inhaler). Di Indonesia pada akhir tahun 2003 beredar obat NiQuitin plester (7 $\mathrm{mg}, 14 \mathrm{mg}$ dan $21 \mathrm{mg}$ ). Untuk perokok sedang dan berat, pengobatan diberikan selama 10 minggu dengan pengurangan dosis bertahap; Harga 1 paket tanpa biaya konsultasi adalah Rp. 1.478.400,- dan untuk perokok ringan, pengobatan diberikan selama 8 minggu, harga 1 paket pengobatan tanpa penghitungan biaya konsultasi adalah Rp. 1.062.600.-

b. Tablet Bupropion yang merupakan obat anti depresan. Obat ini tidak terdapat di pasaran Indonesia.

c. Tablet Varenicline yaitu obat generasi baru yang khusus dikembangkan untuk obat berhenti merokok (Nama dagangnya adalah Champix). Tidak mengandung nikotin sama sekali. Berfungsi agonis parsial yaitu mengikat reseptor nikotin di otak; nikotin di blok sehingga pelepasan Dopamin dikurangi secara parsial. Efek ini mengurangi gejala "craving" (keinginan yang kuat untuk merokok)" dan "sakau". Kurangnya Dopamin juga mengakibatkan kurangnya kepuasan sesaat yang ditimbulkan rokok (disebut efek antagonis).

d. Pengobatan selama 12 minggu (starter pack 1-2 minggu, maintenance 3-12 minggu); Harga Champix masih cukup mahal, per 2 box untuk 2 minggu adalah Rp. 756,663. Jadi untuk 1 paket pengobatan dibutuhkan biaya 6 x Rp. 756,663 = lebih dari Rp. 4,5 juta.

3. Terapi alternatif lain antara lain akupuntur, accupressure dan hipnoterapi.

\section{G. Strategi Dakwah}

Dakwah merupakan proses internalisisi, transformasi, difusi, transmisi nilai-nilai ajaran Islam dalam kehidupan umat. Upaya dakwah Islam 
dilakukan untuk mewujudkan tatakan kehidupan umat yang semakin baik, sejahtera dan bahagia. Dakwah Islam bagi para para pecandu rokok diperlukan sebagai upaya penyadaran dan internalisasi nilai-nilai sosial yang ada di dalam masyarakat, sebagai salah satu wujud upaya mewujudkan kebahagiaan dan keteraturan hidup terbebas dari sesuatu hal yang membawa dampak negative bagi orang lain.

Ada beberapa strategi dakwah yang dapat dilakukan untuk mengurangi tingkat komsumsi rokok pada anak. Mendasarkan pada bentuk kegiatan dakwah islamiyah, maka strategi yang dapat dilakukan dengan optimalisasi pada bentuk kegatan dakwah itu sendiri meliputi kegiatan tabligh, irsyad, tadbir, dan tathwir.

Strategi dakwah melalui kegiatan tabligh menurut Enjang AS, dkk, merupakan strategi yang dianggap lebih mudah dan dapat dilakukan oleh siapa pun, memiliki jangkauan yang tidak terbatas, karena dapat menggunakan pemanfaatan fasilitas media yang berkembang di masyarakat. Tabligh merupakan bentuk kegiatan dakwah yang mendasarkan pada prinsip kerja transsitif yaitu menyampaikan atau mengabarkan pemberitaan tentang ajaran Islam kepada umat manusia, sehingga pemberita terlepas dari beban kewajiban dan pihak penerima berita menjadi terikat dengannya secara kontinu. ${ }^{14}$ Dalam konteks penanganan baby smoker, kegiatan tabligh ini berkaitan pengan penyampaian beban kewajiban (agen dakwah) informasi pengetahuan mengenai rokok dan dampaknya bagi anak-anak. Usia 0-5 tahun merupakan tahap pembentukan kognitif, yang terpenting di sini adalah menyampaikan pengetahuan dan pemahaman kepada anak bahwa merokok memberi efek negatif bagi kesehatan. Agar pemahaman dapat meresap, maka orang tua atau profesional dapat menggunakan media seperti gambar ataupun visualisasi mengenai bahaya merokok bagi kesehatan. Biasanya anak memiliki kecenderungan lebih tertarik pada bentuk gambar maupun visualisasi gambar daripada cerita atau ceramah. Pada usia 6-13 tahun merupakan tahap perkembangan hormon dan sosial. Dalam konteks kegiatan tabligh anak diajak untuk ikut mengkritisi dampak yang ada dalam rokok.

${ }^{14}$ Enjang As, dkk. Dasar-dasar Ilmu Dakwah, (Bandung: Widyapadjajaran, 2009), hlm. 54 
Irsyad berarti bimbingan untuk menginternalisasikan nilai ajaran Islam kedalam setiap aspek kehidupan. Kegiatan irsyad dalam perkembangannya melibatkan dinamika psikologis yang mengarah pada perubahan perilaku sasaran dakwah. Bimbingan ini mendasarkan implementasi metode dakwah pada ketentuan al-Qur'an yaitu hikmah (berarti menyampaiakn sesuatu yang jelas kebenarannya), maudzah hasanah (organisasi pesan dakwah) dan mujadallah (etika dialog yang berakhlak). ${ }^{15}$ Kaitannya dengan strategi dakwah untuk menanggulangi meningkatnya baby smoker, kegiatan irsyad perlu dilakukan khususnya sebagai upaya pendampingan (istilah dalam penyuluhan Islam adalah memainkan fungsi kuratif dan development) dan penyadaran anak untuk menjauhkan diri dari perilaku merokok. Hal ini didasarkan pada pertimbangan bahwa membiarkan anak terjerat dalam perilaku merokok merupakan bentuk pelanggaran perlindungan hak tumbuh dan kembang anak. Irsyad Islam dapat dilakukan dengan memberikan pengertian dan pemahaman sejak dini dengan cara yang tepat, khususnya dampak dari konsumsi rokok bagi kesehatan, psikis dan sosialnya. Irsyad juga dapat berupa keteladanan yang harus ditunjukkan kepada anak, bahwa orang tua, lingkungan dan masyarakat memiliki kepedulian yang tinggi dalam menjaga kebersihan dan kesehatan lingkungan dari asap rokok.

Tadbir Islam merupakan bentuk transformasi ajaran Islam dengan memanfaatkan prinsip dan fungsi manajemen. Kegiatam tadbir Islam juga merupakan kegiatan pelembagaan dan pengelolaan kelembagaan Islam. Kaitannya dengan upaya mengurangi baby smoker, tentu perlu memperhatikan keberadaan lembaga Islam maupun lembaga pemerintah dan non pemerintah. Dalam hal ini posisi lembaga ini sebagai wadah untuk dapat mengatur, mengelola, menyediakan fasilitas (baik aturan, kebijakan, acuan, infrastruktur maupun pelayanan sosial keagamaan bagi masyarakat). Lembaga ini secara sosial bertanggung jawab dalam pengelolaan aturan dan pembuat kebijakan berkaitan dengan pelarangan konsumsi rokok pada anak usia dini, melakukan pengawasan dan evaluasi seluruh aspek yang diduga menjadi pemicu meningkatnya jumlah konsumsi rokok pada anak. Salah satu

${ }^{15}$ Mundir Suparta, dkk. (ed.), Metode Dakwah, (Jakarta: Kencana, 2011), hlm. 39. 
bentuk tanggung jawab lembaga ini adalah bersama-sama dengan masyarakat memberikan perlindungan pada anak, dengan membuat regulasi terhadap keberadaan zat aditif, tembakau (RPP tembakau) dan hal ikhwal rokok.

Tathwir Islam merupakan kegiatan dakwah yang berorientasi pada masalah pengembangan dan pemberdayaan masyarakat. Artinya kegiatan ini lebih mengarah pada upaya peningkatan amalan shaleh dengan pengembangan pranata sosial, dan pengembangan kehidupan masyarakat yang memperhatikan kaidah norma dan aturan sosial masyarakat. Kaitannya dengan keberadaan baby smoker, maka srategi yang dapat dilakukan adalah memanfaatkan peran masyarakat untuk ikut andil dan memiliki kepedualian yang tinggi pada masalah konsumsi rokok. Memberdayakan keluarga untuk mengontrol anak-anaknya. Adanya kepedulian masyarakat untuk sadar rokok, merupakan salah satu strategi mengurangi jumlah konsumsi rokok pada anak. Memberikan pendidikan dan pelatihan, ataupun pendampingan kepada keluarga (miskin dan terpinggir) pencegahan atau upaya berhenti rokok dan lain sebagainya.

\section{H. Simpulan}

Maraknya baby smoker di Indonesia dan lingkungan sekitar kita memerlukan penanganan yang serius, memerlukan partisipasi aktif masyarakat untuk tau, mau tau dan sadar tentang berbagai macam dampak yang ditimbulkan akibat konsumsi rokok bagi anak-anak. Pemerintah telah berupaya secara masksimal melalui penyelenggaraan dan regulasi peraturan tentang larangan merokok ataupun penggunaan zat adatif pada anak-anak, meskipun pelaskanaaan program itu jalan di tempat, masyarakat perlu berpartisipasi aktif dalam mengurangi fenomena maraknya konsumsi rokok pada anak. Secara sosial membiarkan anak mengkonsumsi rokok di usianya yang masih dini, berarti membawa kita ikut ambil bagian dalam merusak generasi penerus kita. Oleh sebab itu mari kita berupaya semaksimal mungin untuk memberikan perlindungan kepada anak-anak bangsa di sekitar kita agar terhindar dari rokok, dan konsumsi rokok apapun bentuknya. Kesadaran ini tentu akan membantu upaya menurunkan angka konsumsi rokok pada anak. 
Upaya lain yang dapat dilakukan untuk mengurangi hal ini adalah dengan mengoptimalkan berbagai bentuk kegiatan dakwah (tabligh, irsyad, tadbir dan tahwir) dalam rangka memberikan pengetahuan dan pemahaman kepada masyarakat mengenai bahaya dan dampak merokok bagi kesehatan. Sosialisasi penting dilakukan mengingat masyarakat masih memiliki pemahaman minim mengenai rokok dan dampaknya. Peran keluarga perlu dioptimalkan untuk memberikan pemahaman yang meresap di hati anak dan kaitannya memberikan tauladan atau keteladanan sadar bahaya rokok.[]

\section{Daftar Pustaka}

Aris dalam Siti Wahyuningsih, Bebaskan Indonesia dari Baby Smoker, Solo: Kementerian Kesehatan Kota Solo, 2012.

Atmarita, "Nutrition Problems in Indonesia", The article for An Integrated International Seminar and Workshop on Lifestyle-Related Diseases, Gajah Mada University, 19-20 March, 2005

Data Komnas Perlindungan Anak, lihat dalam http://www.tribunnews. com/2012/03/15/komnas-perlindungan-anak-desak-rpp-tembakaudisahkan, diakses Selasa, 19 Pebruari 2013

Enjang As, dkk. Dasar-dasar Itmu Dakwah, Bandung: Widyapadjajaran, 2009

FJ. Monks, Psikologi Perkembangan, Yogyakarta: UGM Press, 2006

live is grace | Bahaya Merokok Bagi Kesehatan, Lihat dalam http://w3nny. student.umm.ac.id/2010/02/04/bahaya-merokok-bagi-kesehatan/, diakses 25 Pebruari 2013

Martini, Santi. Muji Sulistiowati. The Determinants of Smoking Behavior among Teenagers in East Java Province, Indonesia: Health, Nutrition and Population (HNP) Discussion Paper Economics of Tobacco Control Paper No. 32. HNP, the World Bank, TFI WHO. December 2005. Lihat dalam www.worldbank.org/hnp and www. worldbank.org/tobacco, diakses 23 Pebruari 2013

Muliarta, "jangan kaget 1.2 juta anak Indonesia perokok aktif", lihat dalam http://www.citizenjurnalism.com/hot-topics/daily-snapshot/jangan-kaget12-juta-anak-indonesia-perokok-aktif/, diakses Selasa, 19 Pebruari 2013. 
Mundir Suparta, dkk. (ed.), Metode Dakwah, Jakarta: Kencana, 2011

Pusat Komunikasi Publik Sekretariat Jendral Kementrian Kesehatan RI, "Laporan Global Adult Tobacco Survey (GATS)," Kementerian Kesehatan RI, 2012

Tjandra Y Aditama. Masalah Merokok dan Penanggulangannya. Yayasan Penerbiyan IDI bekerjasama dengan PDPI dan LM3. Jakarta, 2001

U.S. Department of Health and Human S ervices. Reducing Tobacco Use: A Report of the Surgeon General-Rxecutive Summary. Atlanta, Georgia: U.S. Department of Health and Human Services, Centers for Disease Control and Prevention, National Center for Chronic Disease Prevention and Health Promotion, Office on Smoking and Health, 2000

UHAMKA, Komnas P Anak. Dampak Keterpajanan Iklan Promosi dan Sponsor Rokok terhadap Kognisi, Afeksi dan Perilaku Merokok Anak. Jakarta, 2007.

Vibrant Life. How to Stop Smoking for Life. Vibrant Life: Special Issue no date, hlm.6. www.vibrantlife.com, diakses 25 Pebruari 2013. 
